\title{
Evaluation of bone healing activity of Cissus quadrangularis (Linn), Cryptolepis buchanani, and Sardinella longiceps in Wistar rats
}

\author{
Somasundaram Ramachandran ${ }^{1 *}$, Laith Fadhil ${ }^{1}$, Chandravadivelu Gopi², Masa Amala ${ }^{1}$ and \\ Magharla Dasaratha Dhanaraju ${ }^{3}$
}

\begin{abstract}
Background: The object of the present study is to evaluate the effect of alcoholic extracts of Cissus quadrangularis (CQ), Cryptolepis buchanani (CB), and Sardinella longiceps (SL) either alone or in the combination $(100 \mathrm{mg} / \mathrm{kg})$ in the management of femur bone healing of Wistar albino rats for 8 weeks. After the period of treatment, femur bones were examined by using biochemical, radiographical, and histopathological studies.

Result: Biochemical evaluation results reveal that there is a steep increase of serum calcium level in the experimental animals during the entire period of treatment which led to an adequate supply of serum calcium to the fractured bone for healing and increases the thickness of the femur bones soon compared to control group. It had been estimated by a calibrated ocular micrometer. Radiographical images of the bones also disclose that the complete bridging of fractured bone occurred in the experimental animals after the treatment of natural compound extracts. In addition to that, all the organs of animals were safe in the experimental animals during the entire study.

Conclusion: The present study strongly recommended that these ethanolic extracts (CQCBSL) either alone or in the combination restoring the strength of the bone and reduced bone repairing period due to the rich content of calcium and other natural phytochemicals presents with them.
\end{abstract}

Keywords: Cissus quadrangularis, Cryptolepis buchanani, Sardinella longiceps, Femur bone healing

\section{Background}

Bone fracture is known as a breaking of bone with damage of soft tissues surrounding in it [1]. It is a partial or complete break in the continuity of bone occurred when there is an exposure of a high external force or impact on it [2]. Bone fracture is characterized by pain, inflammation, edema, hematoma, breakdown of periosteum, endosteum, and rupture of soft tissues [3]. There is a need to heal the fractured bone to restore the normal anatomy and prevent the chance of an unusual position [4]. Bone healing is the process in which reformation

\footnotetext{
* Correspondence: ramachandran@giet.ac.in

'Department of Pharmacology, GIET School of Pharmacy, Rajahmundry, Andhra Pradesh 533296, India

Full list of author information is available at the end of the article
}

takes place from the fractured bone which consists of three major phases called inflammatory, repair, and remodelling stages [5]. The practice of the synthetic compounds and minerals with NSAID on fractured bones are raising poor compliance among the patient due to severe side-effects such as swelling, reduction in blood flow, color changes in skin and nails, discomfort, pain, nephrotoxicity, gastrointestinal bleeding, delayed blood clotting, and prolongation of treatment [6]. Therefore, there is a necessity of a newer method of treatment required to treat the fractured bone. The recent literature study stated that usage of phytochemicals in the treatment of bone healing offering promising results without side effects and reducing repair period [7]. In this study, we had taken three varieties of natural sources such as 
Cissus quadrangularis (CQ), Cryptolepis buchanani (CB), and Sardinella Longiceps (SL) for the treatment of bone healing due to the rich content of calcium and other phytochemicals (Fig. 1). CQ is a perennial plant of the grape family commonly found in Sri Lanka and India has been used for different health benefits [8]. It consists of a large number of phytochemicals such as calcium, ascorbic acid, triterpenes, $\beta$-sitosterol, ketosteroid, asymmetrical, and tetracyclic triterpenoids [9]. It is known to have significant activities on diabetes [10], heart disease [11], bone healing [12], cholesterol [13], cancer [14], hemorrhoids [15], ulcer [16], and menstrual disturbances [17]. Similarly, CB is a climber or straggling shrub commonly found in forests of Thailand, China, India, Nepal, and Indo-china [18]. Different parts of this plant used for anti-diarrheal [19], anti-bacterial [20], anti-ulcerative [21], anti-inflammatory [22], rickets [23], anti-diarrheal [24], and blood purifier [25] due to the presence of alkaloids, steroids, glycosides, saponins, flavonoids and tannins, calcium, and phosphates [26]. Sardinella Longiceps (SL) is a species of ray-finned fish found in Indian, Pacific, and Atlantic oceans [27]. It is composed of protein, lipid, carbohydrate, calcium, and minerals [28]. The fish oil is one of the richest and cheapest sources of Eicosapentaenoic acid (EPA), docosahexaenoic acid (DHA), calcium, phosphate, protein, amino acid, minerals, vitamins, and fatty acids exhibits anti-bacterial activity [29], bone and teeth formation, etc., [30]. To the best of our knowledge, it is a pioneer study that demonstrates the effect of mentioned natural compounds as either alone or in combination tested for the healing of fractured bone. The study result reveals that these natural compounds restore the strength of the bone and enhancing the bone repair due to the rich content of calcium and other natural phytochemicals. It is an important milestone in the development of a newer method of bone healing treatment.

\section{Methods}

\subsection{Drugs and chemicals}

Thiopental sodium (Wellona Pharma, India), Diclofenac sodium tablets (GlaxoSmithKline, India), Calcium vitamin $\mathrm{D}_{3}$ tablets (Novartis, Bangladesh), Sodium Hydroxide (Sigma-Aldrich, India), and Ethanol (Gandhi Chemical Corporation, India).

\subsection{Collection of materials}

Excellent quality of Cissus Quadrangularis (CQ), Cryptolepis Buchanani (CB) was collected from a wild-growing plant in Sengottai, Tirunelveli District of Tamil Nadu, India. Collected materials of the plants were identified by Dr. K. Madhava Chetty, Professor, Department of Botany, Sri Venkateshwara University, Thirupathi. The plant materials were dried in a shade and pulverized for bone healing purpose. Sardinella Longiceps was obtained from Kakinada harbor and was identified in State Institute of Fisheries Technology (SIFT).

\subsection{Preparation of extracts}

The whole plant of Cissus quadrangularis, Cryptolepis buchanani was collected from the different sites and washed of dust, impurities using tap water. Similarly, filleting waste of Sardinella Longiceps was separated from bone by boiled with distilled water. The above materials were dried at ambient temperature and pulverized using a blender. A specified quantity of the powder either alone or in the combination was extracted with ethanol by using Soxhlet apparatus at $60{ }^{\circ} \mathrm{C}[31,32]$. Semisolid extracts were stored in the refrigerator until the arrangement of the entire procedure of the experiment. The solvent present in the extracts has been removed by reduced pressure technique. The extract was collected and preserved in a desiccator for further studies. Four extracts of plants and Sardinella Longiceps were prepared as follows:

Extract 1 prepared from $10 \mathrm{~g}$ of Cissus quadrangularis in $100 \mathrm{ml}$ of ethanol.

Extract 2 prepared from $10 \mathrm{~g}$ of Cryptolepis buchanani in $100 \mathrm{ml}$ of ethanol.

Extract 3 prepared from 10 g of Sardinella Longiceps in $100 \mathrm{ml}$ of ethanol.

Extract 4 prepared from $10 \mathrm{~g}$ of a mixture in equal parts of Cissus quadrangularis, Cryptolepis buchanani and Sardinella Longiceps in $100 \mathrm{ml}$ of ethanol.

\subsection{Phytochemical studies}

The extracts of Cissus quadrangularis (CQ), Cryptolepis buchanani (CB), and Sardinella longiceps (SL) either alone or in the combination were subjected to phytochemical studies to get the active chemical compounds present in it. Extracts were sticky, green color, and

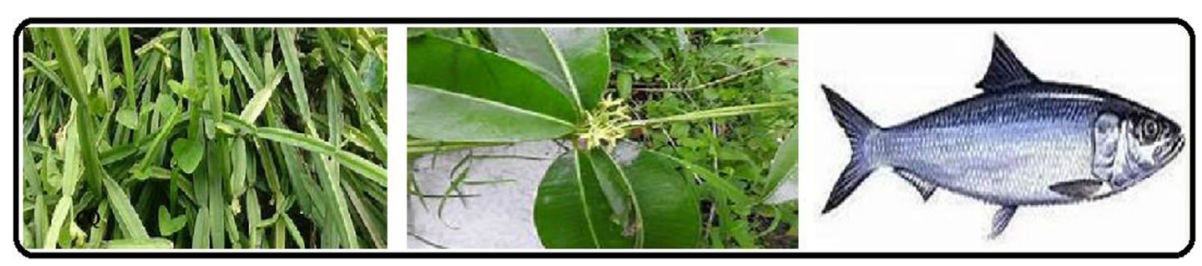

Fig. 1 Images of Cissus quadrangularis (CQ), Cryptolepis buchanani (CB), and Sardinella Longiceps (SL) 
stored at $4{ }^{\circ} \mathrm{C}$ until use. Phytochemical studies were performed according to the official methods prescribed for medicinal compounds using appropriate chemical reagents.

\subsection{Experimental animals}

Wistar albino rats of either sex (150-200 g) were procured from Sainath Agencies, Hyderabad, Telangana, India. The animals were kept in the polypropylene cages and provided with standard rat feed and filtered water ad libitum [33]. The animals were acclimatized for laboratory conditions 1 week before conductance of the study to avoid anxiety in animals. All the experimental animals were housed under standard environmental temperature $\left(23 \pm 2{ }^{\circ} \mathrm{C}\right)$, humidity $(50 \pm 5 \%)$, and $12 \mathrm{~h}$ of light/dark cycles [34]. The husk in the cages was cleaned on every alternate day to ensure hygiene and maximum comfort for animals.

\subsection{Ethics statement}

All experimental procedure and studies performed under the guidelines of scientific experiments on animals as approved by the Institutional animal ethics committee (IAEC) on 2 February 2019 and care of laboratory animals taken for the entire study as per the guidelines of the committee for the purpose of Control and Supervision of Experiments on Animals (CPCSEA). The registration number is GSP/IAEC/2019/02/01.

\subsection{Euthanasia and anesthesia}

To perform the histopathological study, animals were sacrificed by cervical dislocation as it causes extensive damage to the brainstem resulting in immediate unconsciousness and death. Experimental rats were sedated with diethyl ether (5\%) before dislocation.

\subsection{Acute toxicology studies}

The female albino mice (nulliparous and non-pregnant) were subjected to acute toxicity study as per OECD guidelines 423 . Here, every three animals were grouped and treated with the graded dose $(5-5000 \mathrm{mg} / \mathrm{kg})$ of natural extracts in a standard room environment (22 ${ }^{\circ} \mathrm{C}$ ). Administration of extracts was done by oral route after constituted with $0.1 \%$ carboxymethyl cellulose. Restlessness, alertness, fearfulness, and irritabilities were observed in the animals during the 14 days and special

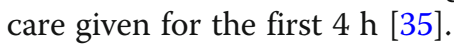

\subsection{Bone healing activity}

The experimental rats were divided into six groups, each group comprising of six animals. Group I animals were administered with $1 \mathrm{ml}$ of $0.1 \%$ carboxymethyl cellulose and considered as a control for 8 weeks. Calcium vitamin D3 tablets $(250 \mathrm{mg} / 125 \mathrm{IU})$ administered to group II animals and had been treated as a standard. Extracts of Cissus quadrangularis (CQ), Cryptolepis buchanani (CB), and Sardinella longiceps (SL) either alone or in the combination were given twice daily to group III to VI containing animals with the dose of $100 \mathrm{mg} / \mathrm{kg}$ body weight. Administration of test and the standard drug was done by oral route after constituted with $0.1 \%$ carboxymethyl cellulose. Experimental animals were examined by biochemical, radiographical, and histopathological studies [36].

\subsection{Biochemical parameter}

Blood was collected from experimental rats by venipuncture using a 20-gauge needle. Blood was centrifuged for $5 \mathrm{~min}$ at $2000 \mathrm{rpm}$ to separate serum. The extracted serum was transferred into the plastic vial and stored at $-80{ }^{\circ} \mathrm{C}$. They were employed for the determination of calcium levels using commercially available kits. Briefly, serum samples were diluted with a buffer in the kit and the amount of calcium was determined. Measurements were recorded every fortnight of experiments [37].

\subsection{Radiographical parameter}

It is a technique used to find out the fractured bone and liable to fracture. All the rats anesthetized with thiopental sodium $(30 \mathrm{mg} / \mathrm{kg})$ by the intraperitoneal route and one of the leg had been shaved on the femur bone, an incision was made by drilling in it with a mini hand electric power driller [38, 39]. The incision was closed and dressed with an antiseptic agent. Animals were subjected to X-ray radiography for evaluation of bone fracture. Extracts were administered to treat the fractured bone of the experimental animals for 8 weeks. The progression of bone healing has been assessed for every week using $\mathrm{X}$-ray radiography and compared the result with control and standard [40].

\subsection{Histopathological parameter}

The liver, kidney, and brain were extracted from the animals according to the guidelines suggested by the committee for supervision and control of animals' experiments. Section of the organs was prepared from paraffin-embedded blocks and was stained with hemotoxylin-eosin. Examination of these organs was

Table 1 Extractive values of natural compounds

\begin{tabular}{ll}
\hline Natural compounds & Extractive values \\
\hline Cissus quadrangularis (CQ) & $9.3 \%$ \\
Cryptolepis buchanani (CB) & $8.5 \%$ \\
Sardinella longiceps (SL) & $12.4 \%$ \\
Mixture (CQCBSL) & $15.3 \%$ \\
\hline
\end{tabular}


Table 2 Phytochemical Constituents of natural compounds

\begin{tabular}{|c|c|c|c|}
\hline Phytochemical constituents & Cissus quadrangularis (CQ) & Cryptolepis buchanani (CB) & Sardinella longiceps (SL) \\
\hline Alkaloids & + & + & - \\
\hline Anthraquinones & + & + & - \\
\hline ascorbic acid & + & - & - \\
\hline Ash & - & - & + \\
\hline calcium & + & + & + \\
\hline carotene & + & - & - \\
\hline Fatty acid & + & + & + \\
\hline Flavonoid & + & + & - \\
\hline Glycoside & - & + & - \\
\hline Kaempferol & + & - & - \\
\hline Minerals & + & + & + \\
\hline Moisture & + & + & + \\
\hline Nicotinic acid & + & - & - \\
\hline Pallidol & + & - & - \\
\hline Parthenocissin & + & - & - \\
\hline Phosphorus & + & - & + \\
\hline Phytosterol & + & + & - \\
\hline Protein & + & - & + \\
\hline Quadrangularins & + & - & - \\
\hline resveratrol & + & - & - \\
\hline Saponins & - & + & - \\
\hline Sugar & + & + & + \\
\hline Tannin & - & + & - \\
\hline Triterpenoids & + & + & - \\
\hline vitamins & + & - & + \\
\hline
\end{tabular}

$(+)$ positive sign indicates present, $(-)$ negative sign indicates absent

Table 3 The result of acute toxicity of alcoholic extracts of natural compounds on Wistar albino rats

\begin{tabular}{|c|c|c|c|c|}
\hline Experimental animals & Alcoholic extract of natural compounds & Dose & Mortality & Symptoms \\
\hline \multirow[t]{15}{*}{ Albino mice (3) } & \multirow[t]{5}{*}{ CQ } & $5 \mathrm{mg} / \mathrm{kg}$ & $0 / 3$ & None \\
\hline & & $50 \mathrm{mg} / \mathrm{kg}$ & $0 / 3$ & None \\
\hline & & 300 mg/kg & $0 / 3$ & Restless, jumping \\
\hline & & $2000 \mathrm{mg} / \mathrm{kg}$ & $0 / 3$ & Motionless, dyspnea \\
\hline & & $5000 \mathrm{mg} / \mathrm{kg}$ & $1 / 3$ & Motionless, dyspnea, death \\
\hline & \multirow[t]{5}{*}{$\mathrm{CB}$} & $5 \mathrm{mg} / \mathrm{kg}$ & $0 / 3$ & None \\
\hline & & $50 \mathrm{mg} / \mathrm{kg}$ & $0 / 3$ & None \\
\hline & & 300 mg/kg & $0 / 3$ & Restless, jumping \\
\hline & & $2000 \mathrm{mg} / \mathrm{kg}$ & $1 / 3$ & Motionless, dyspnea, death \\
\hline & & $5000 \mathrm{mg} / \mathrm{kg}$ & $1 / 3$ & Motionless, dyspnea, death \\
\hline & \multirow[t]{5}{*}{ SL } & $5 \mathrm{mg} / \mathrm{kg}$ & $0 / 3$ & None \\
\hline & & $50 \mathrm{mg} / \mathrm{kg}$ & $0 / 3$ & None \\
\hline & & 300 mg/kg & $0 / 3$ & Restless, jumping \\
\hline & & $2000 \mathrm{mg} / \mathrm{kg}$ & $1 / 3$ & Motionless, dyspnea, death \\
\hline & & $5000 \mathrm{mg} / \mathrm{kg}$ & $2 / 3$ & Motionless, dyspnea, death \\
\hline
\end{tabular}


Table 4 The level of serum calcium in the experimental animals after treating with alcoholic extracts of natural compounds

\begin{tabular}{|c|c|c|c|c|c|}
\hline \multirow[t]{2}{*}{ Treatments } & \multicolumn{5}{|c|}{ Serum calcium level mg/dl } \\
\hline & 0 day & 14 days & 28 days & 42 days & 56 days \\
\hline Control & $4.80 \pm 0.12^{* *}$ & $4.35 \pm 0.34^{*}$ & $4.04 \pm 0.28^{*}$ & $3.98 \pm 0.34^{* *}$ & $3.87 \pm 0.05^{* *}$ \\
\hline Standard & $4.84 \pm 0.15^{*}$ & $5.09 \pm 0.03^{* *}$ & $5.12 \pm 0.16^{* *}$ & $5.23 \pm 0.26^{*}$ & $5.29 \pm 0.47^{*}$ \\
\hline CQ-100 mg/kg & $4.77 \pm 0.19^{* *}$ & $4.89 \pm 0.52^{* *}$ & $4.93 \pm 0.40^{*}$ & $5.01 \pm 0.02^{* *}$ & $5.12 \pm 0.18^{*}$ \\
\hline CB-100 mg/kg & $4.71 \pm 0.40^{* *}$ & $4.84 \pm 0.57^{*}$ & $4.90 \pm 0.29^{* *}$ & $4.98 \pm 0.04^{* *}$ & $5.05 \pm 0.38^{*}$ \\
\hline $\mathrm{SL}-100 \mathrm{mg} / \mathrm{kg}$ & $4.85 \pm 0.07^{*}$ & $4.94 \pm 0.05^{* *}$ & $5.01 \pm 0.42^{* *}$ & $5.09 \pm 0.28^{*}$ & $5.18 \pm 0.31^{* *}$ \\
\hline CQCBSL $100 \mathrm{mg} / \mathrm{kg}$ & $4.81 \pm 0.26^{* *}$ & $5.04 \pm 0.35^{* *}$ & $5.09 \pm 0.18^{*}$ & $5.15 \pm 0.23^{*}$ & $5.22 \pm 0.45^{* *}$ \\
\hline
\end{tabular}

${ }^{*} P<0.005,{ }^{*} P<0.001$ as compared to blank and standard respectively. Statistical analysis-one-way ANOVA

carried out as per the standard histopathological procedure [41].

\section{Results}

\subsection{Phytochemical constituents}

Phytochemical studies on alcoholic extracts of Cissus quadrangularis (CQ), Cryptolepis buchanani (CB), and Sardinella longiceps (SL) either alone or in the combination revealed that the presence of numerous bioactive compounds such as flavonoids, calcium, vitamins, alkaloids, resveratrol, ascorbic acid, phytosterol, triterpenoids, nicotinic acid, carotene, enzyme, quadrangularins, pallidol, parthenocissin, kaempferol, phosphorus, tannins, glycoside, saponins, carbohydrates, anthraquinones, protein, fatty acid, moisture, and ash. Each one is different from the others by appearances, metabolites present in it, and their quantities. Extractive values of $\mathrm{CQ}, \mathrm{CB}, \mathrm{SL}$, and mixture of each in ethanolic solvents are demonstrated in Table 1 . The report of phytochemical studies on natural compounds was summarized in Table 2 .

\subsection{Acute toxicity}

Symptoms and mortality were reported in the group treated with a high dose of alcoholic extract of natural compounds, and there is no such type of lethality and symptoms that were observed at low doses given to the experimental animals either alone or in combination. The report of acute toxicity was furnished in Table 3.

\subsection{Biochemical parameters}

Amount of serum calcium present in the experimental rats was measured at the beginning and every fortnight of the experiment $(0,14,28,42$, and 56 days), and expressed as differences in the blood calcium level in these days. The level of blood calcium in the tested animals continuously increased after an individual or in combination with alcoholic extracts of Cissus quadrangularis (CQ), Cryptolepis buchanani (CB), and Sardinella longiceps (SL). The level of calcium of these tested animals compared with control and standard groups. The results were presented in Table 4.

\subsection{Radiographical parameter}

The experimental rats treated with either individual or in combination with alcoholic extracts of Cissus quadrangularis (CQ), Cryptolepis buchanani (CB), and Sardinella longiceps (SL) showed increasing bone healing compared to the control groups. The level of bone incision gradually reducing in the group treated with extracts due to the adequate level of calcium supply to the

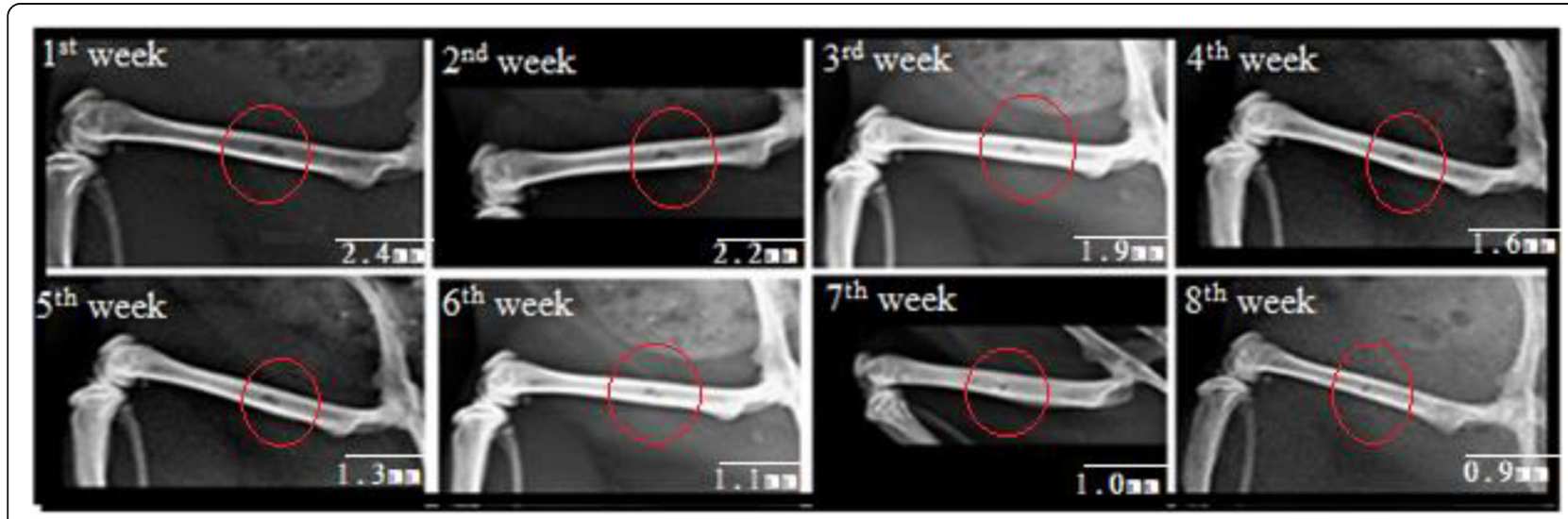

Fig. 2 Different images of a fractured bone in the control group during the period of 8 weeks 


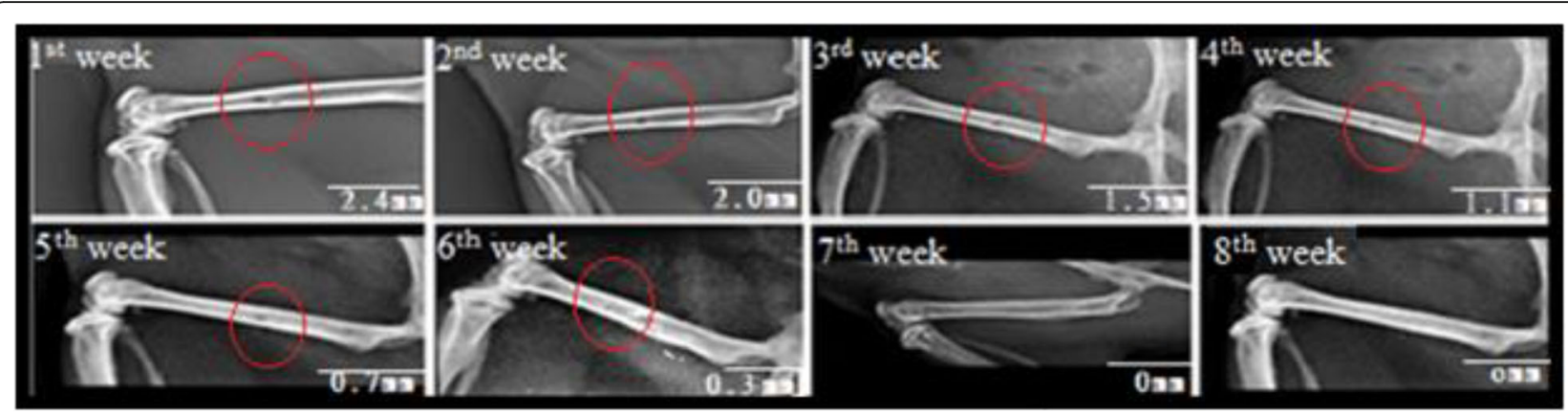

Fig. 3 Different images of a fractured bone in the standard group during the period of 8 weeks

blood. Therefore, serum calcium constantly delivered to the bone having the incision on it. As a result, incisions have vanished from the tested group rapidly when compared with the control group. The size of the incisions has been identified by using X-ray radiographical technique (Figs. 2, 3, and 4).

\subsection{Histopathological studies}

Transverse section of the kidney, liver, and brain were prepared and studied histopathologically. These organs were extracted from the group treated with alcoholic extracts of a mixture of natural compounds and control group at the end of the experiment. The result reveals that these organs were not affected during the study period. Therefore, these extracts are safe to consume for bone healing and bone strength. Here, we demonstrated kidney, liver, and brain transverse section of animals treated with extracts of natural compounds (CQCBSL) and control (Fig. 5).

\subsection{Statistical analysis}

The results obtained in the experiment were assessed by paired $t$ test and one-way ANOVA. The results of the test groups were compared to control and standard, respectively.

\section{Discussion}

The study was designed to evaluate the effect of alcoholic extracts of Cissus quadrangularis (CQ), Cryptolepis buchanani (CB) and Sardinella longiceps (SL) in the management of bone healing of Wistar albino rats. To find out the bone healing properties of alcoholic extracts of natural compounds, incisions were made in the femur bone of experimental animals with an aid of mini hand electric power driller and calculated the initial diameter of the hole. Later, animals were treated with the standard drug and alcoholic extracts of natural compounds. Calcium vitamin $\mathrm{D}_{3}$ tablets are used as a standard drug to find out the calcium supplementary effect of alcoholic extracts of natural compounds obtained from plants and fish. Animals were divided into six groups and each group comprised of six animals. Group I treated as a control group. Group II animals were administered with standard drugs. Test animals (group III to VI) were treated with alcoholic extracts of Cissus quadrangularis, Cryptolepis buchanani, and Sardinella longiceps either alone or combinations $(100 \mathrm{mg} / \mathrm{kg})$. The result reveals that animals treated with natural compounds either individual or in combination significantly restored the serum calcium throughout the experiment and induces the bone healing process in the fractured bone of the tested albino rats. Amount of serum calcium in the

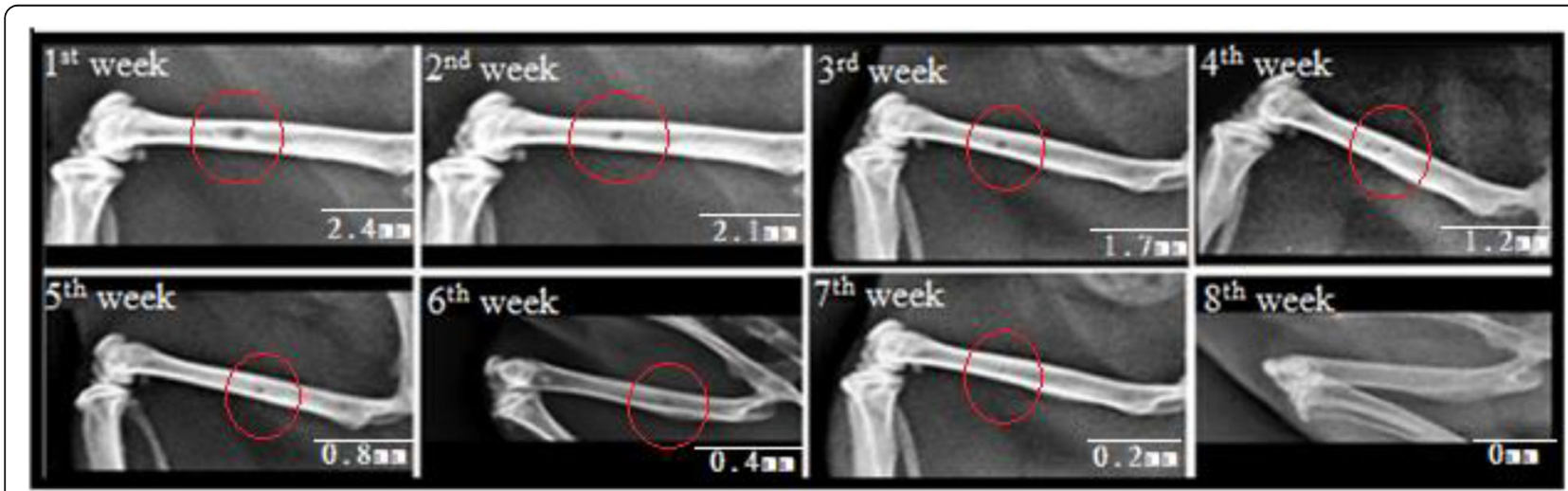

Fig. 4 Different images of a fractured bone in the group treated with a mixture of natural compounds during the period of 8 weeks 


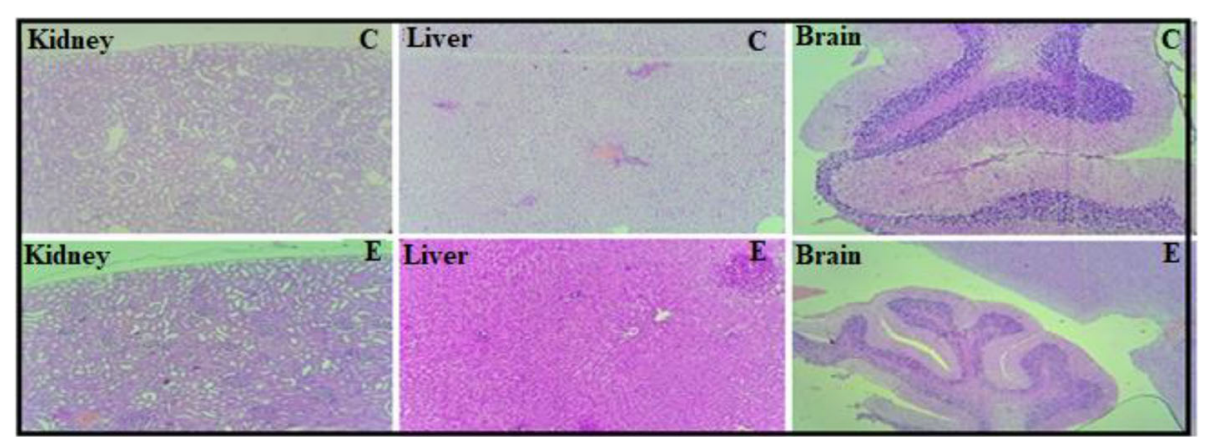

Fig. 5 Histopathological sections of the kidney, liver, and brain of control and group treated with a mixture of natural compounds (CQCBSL)

experimental animals was measured at every fortnight of the experiment with the aid of kit. Each of the extract offering a varying degree of serum calcium in the tested animals is listed in Table 2. Combination of natural compound extracts (CQCBSL) significantly raising the level of serum calcium throughout the experiment and reached the final score of $5.22 \pm 0.45 \mathrm{mg} / \mathrm{dl}$ in the tested animals. The value is very closer to the group treated with the standard drug. Furthermore, extracts were prepared from individual natural compounds exhibited a different level of serum calcium in the tested animals and recorded $5.18 \pm 0.31 \mathrm{mg} / \mathrm{dl}(\mathrm{SL}), 5.12 \pm 0.38 \mathrm{mg} / \mathrm{dl}$ (CQ), $5.07 \pm 0.38 \mathrm{mg} / \mathrm{dl}(\mathrm{CB})$ at the end of the 56th day. The size of bone incision gradually reduces every week in the group treated with alcoholic extracts of natural compounds due to the adequate level of calcium supply to the blood. Therefore, serum calcium constantly delivered to the bone having the incision on it. A clear system is existing between alcoholic extracts of natural compounds and serum level in the tested animals. The hole in the femur bone of tested animals and standard has vanished at the end of experiments, but it has been persisting in the control group after 8 weeks. It has been identified every week by using X-ray radiographical technique and are summarized in Figs. 2, 3, and 4. At last, a histopathological study was measured after sacrificing the animals. The kidney, liver, and brain of the experimental animals were healthy at the end of the experiment. Histopathological studies were summarized in Fig. 5. These extracts are safe to consume for bone healing and bone strength. The order of the bone healing effect of these alcoholic extracts of natural compounds was found to be CQCBSL'SL'CQ’CB.

\section{Conclusion}

Our study demonstrated that individual or combination of alcoholic extracts of Cissus quadrangularis, Cryptolepis buchanani, and Sardinella longiceps enhance the bone healing process in the tested animals due to the presence of different phytochemicals. These phytochemicals raise the level of serum calcium which led to speed up the bone healing and bone strength. Moreover, the combination of alcoholic extracts of natural compounds considerably reduces the time period of bone healing in the experimental rats as similar to that of standard drug. Thus, Cissus quadrangularis, Cryptolepis buchanani, and Sardinella longiceps are promising agents for the management of bone healing by restoring the calcium without inducing side effects.

\section{Abbreviations \\ CQ: Cissus quadrangularis; CB: Cryptolepis buchanani; SL: Sardinella longiceps: CQCBSL: A mixture of Cissus quadrangularis, Cryptolepis buchanani and Sardinella longiceps; NSAID: Non-steroidal anti-inflammatory drugs; DHA: Docosahexaenoic acid; EPA: Eicosapentaenoic acid; OECD: The organisation for economic cooperation and development; ANOVA: Analysis of variance}

\section{Acknowledgements}

All authors wish to express the gratitude to GIET School of Pharmacy, Rajahmundry, Andhra Pradesh, India, for providing research facilities.

\section{Authors' contributions}

SR designed the study, data collection, administered the treatment based on the randomization table, and prepared the first draft of the manuscript. LF involved for collection of natural compounds and performed the study. CG and MA had integrated the data of the manuscript and contributed the major work in the anesthetic procedure of the entire study. MDD wrote the manuscript in a journal format and surgical procedure of the experimental animals. All the authors have read and approved the manuscript.

\section{Funding}

There is no external funding for this project. Authors of this manuscript contributed their money to meet the expenses.

Availability of data and materials

All the data generated and analyzed during the study are included in the manuscript.

\section{Declarations}

\section{Ethics approval and consent to participate}

All experimental procedure and studies performed under the guidelines of scientific experiments on animals as approved by the Institutional animal ethics committee (IAEC) on 2 February 2019 and care of laboratory animals taken for the entire study as per the guidelines of the committee for the purpose of Control and Supervision of Experiments on Animals (CPCSEA). The registration number is GSP/IAEC/2019/02/01. 


\section{Consent for publication}

Not applicable.

\section{Competing interests}

The authors declare that they have no competing interests.

\section{Author details}

'Department of Pharmacology, GIET School of Pharmacy, Rajahmundry, Andhra Pradesh 533296, India. 'Department of Pharmaceutical Chemistry, GIET School of Pharmacy, Rajahmundry, Andhra Pradesh 533296, India. ${ }^{3}$ Research Lab, GIET School of Pharmacy, Rajahmundry, Andhra Pradesh 533296, India.

\section{Received: 4 January 2021 Accepted: 16 April 2021}

\section{Published online: 01 May 2021}

\section{References}

1. Chen TH, Weber FE, Malina-Altzinger J, Ghayor C (2019) Epigenetic drugs as new therapy for tumor necrosis factor-a-compromised bone healing. Bone 127:49-58. https://doi.org/10.1016/j.bone.2019.05.035

2. Romani WA, Gieck JH, Perrin DH, Saliba EN, Kahler DM (2002) Mechanisms and management of stress fractures in physically active persons. J Athl Train 37(3):306-314 PMCID: PMC164361

3. Lee YJ, Sadigh S, Mankad K, Kapse N, Rajeswaran G (2016) The imaging of osteomyelitis. Quant Imaging Med Surg 6(2):184-198. https://doi.org/10.21 037/qims.2016.04.01

4. Singer LD (2015) The importance of immediate bone block autograft to successfully restore the function and aesthetic of the anterior alveolar process and teeth. J Oral Implantol 41(6):684-691. https://doi.org/10.1 563/AAID-JOI-D-13-00332

5. Schindeler A, McDonald MM, Bokko P, Little DG (2008) Bone remodeling during fracture repair: the cellular picture. Semin Cell Dev Biol 19(5):459466. https://doi.org/10.1016/j.semcdb.2008.07.004

6. Garcia-Martinez O, Luna-Bertos ED, Ramos-Torrecillas J, Manzano-Moreno FJ, Ruiz C (2015) Repercussions of NSAIDS drugs on bone tissue: the osteoblast. Life Sci 123:72-77. https://doi.org/10.1016/j.lfs.2015.01.009

7. Jalil MAA, Shuid AN, Muhammad N (2012) Role of medicinal plants and natural products on osteoporotic fracture healing. Evid Based Complement Alternat Med 714512:1-7. https://doi.org/10.1155/2012/714512

8. Gupta MM, Verma RK (1991) Lipid constituents of Cissus quadrangularis. Phytochemistry 30(3):875-878. https://doi.org/10.1016/0031-9422(91)852 70-A

9. Parvathi K, Krishnan AG, Anitha A, Jayakumar R, Nair MB (2018) Poly (L-lactic acid) nanofibers containing Cissus quadrangularis induced osteogenic differentiation in vitro. Int J Biol Macromol 110:514-521. https://doi.org/10.1 016/j.ijbiomac.2017.11.094

10. Oben J, Kuate D, Agbor G, Momo C, Talla X (2006) The use of a Cissus quadrangularis formulation in the management of weight loss and metabolic syndrome. Lipids Health Dis 5(1):24. https://doi.org/10.1186/1476$511 X-5-24$

11. Oben JE, Ngondi JL, Momo CN, Agbor GA, Sobgui CSM (2008) The use of a Cissus quadrangularis/Irvingia gabonensis combination in the management of weight loss: a double-blind placebo-controlled study. Lipids Health Dis 7(1):12. https://doi.org/10.1186/1476-511X-7-12

12. Singh V, Singh N, Pal US, Dhasmana S, Mohammad S, Singh N (2011) Clinical evaluation of Cissus quadrangularis and moringa oleifera and osteoseal as osteogenic agents in mandibular fracture. Natl J Maxillofac Surg 2(2):132-136. https://doi.org/10.4103/0975-5950.94466

13. Oben JE, Enyegue DM, Fomekong GI, Soukontoua YB, Agbor GA (2007) The effect of Cissus quadrangularis (CQR-300) and a Cissus formulation (CORE) on obesity and obesity-induced oxidative stress. Lipids Health Dis 6(4):1-8. https://doi.org/10.1186/1476-511X-6-4

14. Suresh P, Xavier AS, Karthik VP, Punnagai K (2019) Anticancer activity of Cissus quadrangularis L. Methanolic extract against MG63 human osteosarcoma cells-an in-vitro evaluation using cytotoxicity assay. Biomed Pharmacol J 12(2):975-980. https://doi.org/10.13005/bpj/1724

15. Panthong A, Supraditaporn W, Kanjanapothi D, Taesotikul T, Reutrakul V (2007) Analgesic, anti-inflammatory and venotonic effects of Cissus quadranaularis Linn. J Ethnopharmacol 110(2):264-270. https://doi.org/10.1 016/j.jep.2006.09.018
16. Jainu M, Devi CSS (2006) Gastroprotective action of Cissus quadrangularis extract against NSAID induced gastric ulcer: role of proinflammatory cytokines and oxidative damage. Chem Biol Interact 161(3):262-270. https:// doi.org/10.1016/j.cbi.2006.04.011

17. Shirwaikar A, Khan S, Malini S (2003) Antiosteoporotic effect of ethanol extract of Cissus quadrangularis Linn. On ovariectomized rat. J Ethnopharmacol 89(2):245-250. https://doi.org/10.1016/j.jep.2003.08.004

18. Pande M, Dubey VK, Yadav SC, Jagannadham MV (2006) A novel serine protease cryptolepain from Cryptolepis buchanani. Purification and biochemical characterization. J Agric Food Chem 54(26):10141-10150. https://doi.org/10.1021/jf062206a

19. Laupattarakasem $P$, Wangsrimongkol T, Surarit $R$, Hahnvajanawon C (2006) In vitro and in vivo anti-inflammatory potential of Cryptolepis buchanani. J Ethnopharmacol 108(3):349-354. https://doi.org/10.1016/j.jep.2006.05.029

20. Vinayaka KS, Prashith KTR, Mallikarjun N, Sateesh VN (2010) Antidermatophyte activity of Cryptolepis buchanani Roem. \& Schult. Phcog J 2(7):170-172. https://doi.org/10.1016/S0975-3575(10)80086-0

21. Hanprasertpong N, Pantong A, Sangdee C, Kunanusorn P, Kasitanon N, Lhieochaiphant S, Teekachunhatean S (2017) Cryptolepis buchanani oil formulation versus indomethacin solution in topical therapy for osteoarthritis of the knee: a randomized controlled trial. J Herb Med 7:1826. https://doi.org/10.1016/j.hermed.2017.01.001

22. Kaul A, Bani S, Zutshi U, Suri KA, Satti NK, Suri OP (2003) Immunopotentiating properties of cryptolepis buchanani root extract. Phytother Res 17(10):1140-1144. https://doi.org/10.1002/ptr.1186

23. Venkateswara R, Narendra N, Viswamitra MA, Vaidyanathan CS (1989) Cryptosin, a cardenolide from the leaves of cryptolepis buchanani. Phytochemistry 28(4):1203-1205. https://doi.org/10.1016/0031-9422(89)802 09-2

24. Rao HCY, Santhosh P, Rakshith D, Sathish S (2015) Molecular characterization of an endophytic phomopsis liquidambaris CBR-15 from Cryptolepis buchanani Roem. And impact of culture media on biosynthesis of antimicrobial metabolites. 3 Biotech 5:165-173. https://doi.org/10.1007/ s13205-014-0204-2

25. Pande M, Dubey VK, Jagannadham MV (2007) Crystallization and preliminary $\mathrm{x}$-ray analysis of cryptolepain, a novel glycosylated serine protease from Cryptolepis buchanani. Acta Cryst F63:74-77. https://doi.org/10.1107/\$17443 09106054807

26. Hanprasertpong N, Teekachuhatean S, Chaiwongsa R, Ongchai S, Kunanusorn P, Sangdee C, Panthong A, Bunteang S, Nathasaen N, Reutrakul $\checkmark$ (2014) Analgesic, anti-inflammatory, and chondroprotective activities of Cryptolepis buchanani extract: in vitro and in vivo studies. Biomed Res Int 978582. https://doi.org/10.1155/2014/978582

27. Vijayapoopathi S, Ayyaru G, Kuzhanthaivel R, Syed A (2016) Lymphocystis in Indian oil sardine, Sardinella longiceps (Valenciennes 1847). Asian Pac J Trop Dis 6(8):611-614. https://doi.org/10.1016/S2222-1808(16)61095-2

28. Chakraborty K, Joseph D, Joseph D (2016) Concentration and stabilization of C20-22 n-3 polyunsaturated fatty acid esters from the oil of Sardinella longiceps. Food Chem 199:828-837. https://doi.org/10.1016/j.foodchem.2015.12.082

29. Mohan CO, Ravishankar CN, Lalitha KV, Gopal TKS (2012) Effect of chitosan edible coating on the quality of double filleted Indian oil sardine (Sardinella longiceps) during chilled storage. Food Hydrocoll 26(1):167-174. https://doi. org/10.1016/j.foodhyd.2011.05.005

30. Logesh AR, Pravinkumar M, Raffi SM, Kalaiselvam M (2012) Calcium and phosphorus determination in bones of low value fishes, Sardinella longiceps (Valenciennes) and Trichiurus savala (Cuvier), from Parangipettai, southeast coast of India. Asian Pac J Trop Dis 2:S254-S256. https://doi.org/10.1016/ S2222-1808(12)60160-1

31. Muthusami S, Ramachandran I, Krishnamoorthy S, Govindan R, Narasimhan S (2011) Cissus quadrangularis augments IGF system components in human osteoblast like SaOS-2 cells. Growth Hormon IGF Res 21(6):343-348. https:// doi.org/10.1016/j.ghir.2011.09.002

32. Padmalochana K, Rajan MSD, Lalitha R, Sivasankari H (2013) Evaluation of the antioxidant and hepatoprotective activity of Cryptolepis buchanani. J Appl Pharm Sci 3(02):99-104. https://doi.org/10.7324/JAPS.2013.30217

33. D'Souza UJA (2003) Toxic effects of 5-fluorouracil on sperm count in Wistar rats. Malays J Med Sci 10(1):43-45 PMCID: PMC3557108

34. Ramachandran S, Nikitha J, Gopi C, Amala M, Dhanaraju MD (2020) Effect of Prunus dulcis and salvia Hispenica in the management of polycystic ovary syndrome in Wistar rats. J Taibah Univ Med Sci 15(2):122-128. https://doi. org/10.1016/j.jtumed.2020.02.002 
35. Jonsson M, Jestoi M, Nathanail AV, Kokkonen UM, Anttila M, Koivisto $P$, Karhunen P, Peltonen K (2013) Application of OECD guideline 423 in assessing the acute oral toxicity of moniliformin. Food Chem Toxicol 53:2732. https://doi.org/10.1016/j.fct.2012.11.023

36. Zandi M, Dehghan A, Amini P, Rezaeian L, Doulati S (2017) Evaluation of mandibular fracture healing in rats under zoledronate therapy: a histologic study. Injury 48(12):2683-2687. https://doi.org/10.1016/j.injury.2017.10.026

37. Chen LR, Wen YT, Kuo CL, Chen KH (2014) Calcium and vitamin D supplementation on bone health: current evidence and recommendations. Int J Gerontol 8(4):183-188. https://doi.org/10.1016/j.jige.2014.06.001

38. Hoheisel U, Unger T, Mense S (2005) Excitatory and modulatory effects of inflammatory cytokines and neurotrophins on mechanosensitive group IV muscle afferents in the rat. Pain 114(1-2):168-176. https://doi.org/10.1016/j. pain.2004.12.020

39. Zinsalo JM, Lamarche L, Raymond J (2020) Injection strategies in an enhanced geothermal system based on discrete fractures model. App Therm Eng 169:114812. https://doi.org/10.1016/j.applthermaleng.2019.114 812

40. Jonasson $T H$, Zancan R, de Oliveira AL, Fonseca AC, Silva MCD, Giovanini AF, Zielak JC, Araujo MR (2017) Effects of low-level laser therapy and platelet concentrate on bone repair: histological, histomorphometric, immunohistochemical, and radiographic study. J Craniomaxillofac Surg 45(11):1846-1853. https://doi.org/10.1016/j.jcms.2017.08.008

41. Akca EK, Atalay B, Oner B (2020) Histopathologic and immunohistochemical investigation of the effects of vitamin $\mathrm{C}$ on bone healing in rats exposed to nicotine. J Oral Maxillofac Surg 78(2):194-194.e14. https://doi.org/10.1016/i. joms.2019.09.006

\section{Publisher's Note}

Springer Nature remains neutral with regard to jurisdictional claims in published maps and institutional affiliations.

\section{Submit your manuscript to a SpringerOpen ${ }^{\circ}$ journal and benefit from:}

- Convenient online submission

- Rigorous peer review

- Open access: articles freely available online

High visibility within the field

- Retaining the copyright to your article

Submit your next manuscript at $\boldsymbol{\nabla}$ springeropen.com 